\title{
Source apportionment of fine organic aerosols in Beijing
}

\author{
Q. Wang, M. Shao, Y. Zhang, Y. Wei, M. Hu, and S. Guo \\ State Joint Key Laboratory of Environmental Simulation and Pollution Control, College of Environmental Sciences and \\ Engineering, Peking University, Beijing, 100871, China
}

Received: 9 December 2008 - Published in Atmos. Chem. Phys. Discuss.: 3 April 2009

Revised: 27 October 2009 - Accepted: 27 October 2009 - Published: 12 November 2009

\begin{abstract}
Fine particles $\left(\mathrm{PM}_{2.5}\right.$, i.e., particles with an aerodynamic diameter of $\leq 2.5 \mu \mathrm{m}$ ) were collected from the air in August 2005, August-September 2006, and JanuaryFebruary 2007, in Beijing, China. The chemical compositions of particulate organic matter in the ambient samples were quantified by gas chromatography/mass spectrometry. The dominant compounds identified in summertime were $n$-alkanoic acids, followed by dicarboxylic acids and sugars, while sugars became the most abundant species in winter, followed by polycyclic aromatic hydrocarbons, $n$ alkanes, and $n$-alkanoic acids. The contributions of seven emission sources (i.e., gasoline/diesel vehicles, coal burning, wood/straw burning, cooking, and vegetative detritus) to particulate organic matter in $\mathrm{PM}_{2.5}$ were estimated using a chemical mass balance receptor model. The model results present the seasonal trends of source contributions to organic aerosols. Biomass burning (straw and wood) had the highest contribution in winter, followed by coal burning, vehicle exhaust, and cooking. The contribution of cooking was the highest in summer, followed by vehicle exhaust and biomass burning, while coal smoke showed only a minor contribution to ambient organic carbon.
\end{abstract}

\section{Introduction}

The continuous increase in city sizes and the progress of industrialization, together with rapid increases in the number of vehicles on the roads and energy consumption, have resulted in very severe $\mathrm{PM}_{2.5}$ (i.e., particles with an aerodynamic diameter of $\leq 2.5 \mu \mathrm{m}$ ) pollution in Beijing. Moreover, emissions from Beijing have a major impact on regional air quality, with the annual average $\mathrm{PM}_{2.5}$ concentration in Beijing

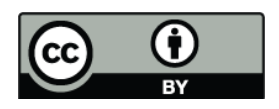

Correspondence to: M. Shao

(mshao@pku.edu.cn) being seven times higher than the ambient standard recommended by the US Environmental Protection Agency (EPA) (Wang et al., 2004). Particulate organic matter (POM) makes up a significant fraction of the $\mathrm{PM}_{2.5}$ mass concentration in Beijing. Zheng et al. (2005) reported that carbonaceous species were the most abundant components in fine particles in Beijing, accounting for 17-65\% of the mass concentration of $\mathrm{PM}_{2.5}$ (average, 35\%), and the organic carbon (OC) concentrations were higher in January and October but lower in July. Song et al. (2007) also reported that organic matter was the largest contributor to ambient $\mathrm{PM}_{2.5}$ (43\% in January and $29 \%$ in August), while the contribution of elemental carbon (EC) to $\mathrm{PM}_{2.5}$ was $8 \%$ in Beijing.

High concentrations of $\mathrm{PM}_{2.5}$ lead to several environmental problems in Beijing. For example, Song et al. (2003) reported that optical extinction by light scattering of particles, especially fine particles, was the main reason for visibility impairment in Beijing. A recent epidemiologic study also confirmed associations between ambient $\mathrm{PM}_{2.5}$ levels and both morbidity and mortality (Pope and Dockery, 2006). Therefore, air quality in Beijing must be improved for human health protection.

A quantitative understanding of the sources of $\mathrm{PM}_{2.5}$ is essential for the development of effective control strategies. Many previous studies on source apportionment of $\mathrm{PM}_{2.5}$ in Beijing used elemental tracers to characterize sources (Song and Xie, 2006; Song et al., 2006, 2007; Sun et al., 2006). The major problem with this approach is that many emission sources do not have a unique elemental composition. Many important $\mathrm{PM}_{2.5}$ sources, such as cooking of food, diesel/gasoline engine exhaust, and cigarette smoke, emit mainly organic compounds and elemental carbon (Hildemann et al., 1991; Schauer et al., 1996; Cass, 1998). The high percentages of organic matter in $\mathrm{PM}_{2.5}$ make organic molecular tracers critically important to identify sources of carbonaceous aerosols and ambient $\mathrm{PM}_{2.5}$. Zheng et al. (2005) explored the major sources of $\mathrm{PM}_{2.5}$ in

Published by Copernicus Publications on behalf of the European Geosciences Union. 
Beijing based on organic compounds using a chemical mass balance (CMB) model; however, the source profiles used in their model were mostly results obtained in the United States, which would not represent the characteristics of local sources in Beijing. A very limited amount of research has examined the chemical compositions of POM source profiles that may be specific for China, such as the cooking of food (He et al., 2004; Zhao, 2006; Zhao et al., 2007) and residential coal burning (Chen et al., 2005; Zhang et al., 2008).

In the present study, $\mathrm{PM}_{2.5}$ samples collected in both summer and winter from 2005 to 2007 in Beijing were analyzed by gas chromatography/mass spectrometry (GC-MS) to determine the concentrations of speciated organic compounds. The source contributions to ambient POM were estimated using a CMB model calculation, based on the source profiles of POM derived from direct measurements of local emission sources. The seasonal trends of source contributions to fine organic aerosols were examined and compared with the results of previous studies in Beijing.

\section{Experimental methods}

\subsection{Samples of ambient $\mathbf{P M}_{2.5}$}

Beijing, the capital city of China, is located at the northern tip of the Chinese Northern Plain and enjoys a moderate continental climate. Due to the control of low-pressure circulation, the frequency of weather unfavorable for the diffusion of air pollutants is about $45 \%$ (Yu et al., 2002), mainly in winter. In the present study, samples were obtained at a site at the top of a building (about $15 \mathrm{~m}$ above the ground) on the campus of Peking University, located $17 \mathrm{~km}$ northwest of the Beijing City center and surrounded by heavy traffic, restaurants, residential areas, and research institutions. The site was considered to be representative of the urban $\mathrm{PM}_{2.5}$ pollution in Beijing (Huang et al., 2006).

Focusing on the air pollution conditions in summer (the time of the Olympics) in Beijing, 12-h samples of ambient fine particles $\left(\mathrm{PM}_{2.5}\right)$ were collected from 2 to 31 August 2005, (Summer I) and from 16 August to 10 September 2006 (Summer II). Sampling was performed from 08:00 to 20:00 h during the daytime and from 20:00 to 08:00 $\mathrm{h}$ the following morning for the nighttime measurements. The sampler used in Summer I was a high-volume sampler (Anderson), operated at a flow rate of $1.13 \mathrm{~m}^{3} / \mathrm{min}$. Quartz fiber filters were used for aerosol collection, and then analyses of OC, EC, and speciated organic compounds were performed. A fourchannel sampler (TH-16A; Wuhan Tianhong Company) was used to collect aerosols in Summer II. Ambient air passing through a cyclone separator at a flow rate of $16.71 / \mathrm{min}$ was collected simultaneously on four parallel filters (two Teflon filters and two quartz fiber filters) during each 12-h sampling period. Samples on Teflon filters were used for measurement of fine particle mass concentrations, while those on quartz fil- ters were used for analysis of $\mathrm{OC}, \mathrm{EC}$, and speciated organic compounds.

In addition, Beijing has distinct space-heating and nonspace-heating periods. In the space-heating season (December to March), the coal consumption per month is about double that in the non-space-heating months. To determine the differences in $\mathrm{PM}_{2.5}$ chemical compositions and sources between these two seasons, 12-h samples of ambient fine particles $\left(\mathrm{PM}_{2.5}\right)$ were also collected from 16 January to 2 February 2007 (Winter), using the same sampler and sampling cycles as in Summer II.

\subsection{Chemical analysis}

The mass concentrations of $\mathrm{PM}_{2.5}$ in Summer II and Winter were obtained by weighing Teflon filters using a microbalance (Mettler AE 204) in a clean room at $25^{\circ} \mathrm{C}$ and relative humidity of $50 \%$ before and after sampling. One punch $\left(1.5 \mathrm{~cm}^{2}\right)$ was taken from each quartz filter for EC and $\mathrm{OC}$ analysis via a thermal-optical method using a Sunset Laboratory-based instrument (NIOSH, 1996). The rest of the quartz fiber filter was then extracted and analyzed using an Agilent GC-MS system (6890 plus GC-5973N MSD) to determine the chemical composition of POM. The quartz filters from several consecutive days were combined to meet the limits of detection for speciated organic compounds. Therefore, the concentrations of POM were average concentrations of several days.

The organic species were identified and quantified using authentic standards and internal standards. The details of the analytical procedures have been described previously (Zhang et al., 2007). Briefly, the samples were first spiked with a mixture of 26 deuterated compounds and 2 carbon isotope $\left({ }^{13} \mathrm{C}\right)$-substituted compounds, and then ultrasonically extracted with dichloromethane/methanol $(3: 1, \mathrm{v} / \mathrm{v})$ at room temperature. The extracts were filtered and concentrated using a rotary vacuum evaporator and further condensed to about $1 \mathrm{ml}$ under a flow of high purity nitrogen. Each extract was split into two fractions, one of which was derivatized with BSTFA (BSTFA/TMCS, 99:1; Supelco) to convert polar organic compounds to trimethyl silanized derivatives. Both the derivatized and underivatized fractions were analyzed using an Agilent GC-MS equipped with an Agilent DB-5MS GC column (length, $30 \mathrm{~m}$; diameter, $0.25 \mathrm{~mm}$; film thickness, $0.25 \mu \mathrm{m})$. The GC temperature program was as follows: isothermal hold at $65^{\circ} \mathrm{C}$ for $10 \mathrm{~min}$, temperature ramp of $10^{\circ} \mathrm{C} / \mathrm{min}$ to $300^{\circ} \mathrm{C}$, with an isothermal hold at $300^{\circ} \mathrm{C}$ for $30 \mathrm{~min}$.

In total, 114 organic compounds were quantified, including sugars, methoxylated phenols, polycyclic aromatic hydrocarbons (PAHs), $n$-alkanes, $n$-alkanols, and sterols. Correlation coefficients $\left(R^{2}\right)$ of calibration curves for standard compounds were $0.996 \pm 0.014$. Spiked filters were analyzed to determine the overall efficiency of the measurements, and the average recoveries were $60.2-116.3 \%$. Field blanks were 
Table 1. The weighting factors for the source profile calculation for POM in $\mathrm{PM}_{2.5}$ from different vehicle exhausts.

\begin{tabular}{|c|c|c|c|c|c|}
\hline & nicle types & $\begin{array}{l}\text { Vehicle num- } \\
\text { ber }\left(10^{4}\right)\end{array}$ & $\begin{array}{l}\text { Annual average } \\
\text { travel distance } \\
10^{4} \mathrm{~km}\end{array}$ & $\begin{array}{l}\text { Emission } \\
\text { factor }^{\mathrm{a}} \mathrm{g} / \mathrm{km}\end{array}$ & $\begin{array}{l}\text { Weighting } \\
\text { factors }\end{array}$ \\
\hline \multirow[t]{5}{*}{ Gasoline vehicles } & Light-duty & 160 & 5.0 & 0.0117 & 0.573 \\
\hline & $\begin{array}{l}\text { Heavy duty with electronic } \\
\text { fuel-injection and } 3 \text {-way cat- } \\
\text { alyst }\end{array}$ & 2.2 & 3.8 & 0.145 & 0.075 \\
\hline & $\begin{array}{l}\text { Heavy duty carburetor with 3- } \\
\text { way catalyst }\end{array}$ & 2.2 & 3.8 & 0.0589 & 0.031 \\
\hline & Heavy duty carburetor & 2.2 & 3.8 & 0.32076 & 0.167 \\
\hline & Motorcycles & 26.5 & 1.2 & 0.07863 & 0.154 \\
\hline \multirow[t]{2}{*}{ Diesel vehicles } & Heavy duty & 13.6 & 3.7 & 0.22134 & 0.248 \\
\hline & Light duty & 25.9 & 4.7 & 0.27772 & 0.752 \\
\hline
\end{tabular}

a data from Zhang (2006)

analyzed and subtracted from all the samples. Laboratory blanks (using a blank filter instead of a sample filter) were also added during sample analysis to evaluate the possible contamination during laboratory analysis.

\subsection{Source apportionment by the CMB model}

A chemical mass balance (CMB8.2) receptor model was used to apportion sources of carbonaceous aerosols in Beijing. The indicators for acceptable fitting results were $R^{2}$ (target $>0.8), \chi^{2}$ (target $<4$ ), degrees of freedom (DF, target $>5$ ), percentage of aerosol mass explained by the sources (target 80-120\%), C/M ratio (ratio of calculated to measured concentration, target 0.5-2.0), and absolute value of the R/U ratio (ratio of residual to uncertainty, target $<2$ ).

The selection of fitting species is critically important as they should be stable during transportation from the source to receptor site, quantifiable in both source tests and the ambient atmosphere, and representative of the chemical characteristics of sources. Based on the work of Schauer et al. (1996), Schauer and Cass (2000), and Fraser et al. (2003), the organic compounds used as fitting species in the CMB model in this study included $n$-alkanes (C26-C33), $n$-alkanoic acids (C16-C18, C20, C22), PAHs (benzo[e]pyrene, benzo[ghi]perylene, coronene), hopanes $(17 \beta(\mathrm{H})-21 \alpha(\mathrm{H})-30$-norhopane, $17 \alpha(\mathrm{H}), 21 \beta(\mathrm{H})$-hopane, 22R-17 $\alpha(\mathrm{H}), 21 \beta(\mathrm{H})$-homohopane, $22 \mathrm{~S}-17 \alpha(\mathrm{H}), 21 \beta(\mathrm{H})-$ homohopane, and $22 \mathrm{~S}-17 \beta(\mathrm{H}), 21 . \beta(\mathrm{H})$-bishomohopane), levoglucosan, cholesterol, and campesterol. EC was also applied to further separate gasoline vehicle and diesel vehicle exhaust. The POM source profiles of diesel/gasoline vehicle exhausts, coal burning, wood/straw combustion, and cooking were taken from local studies in China (Zhang, 2006; Zhang et al., 2007, 2008; Zhao et al., 2007). Only the source profile that described emissions of vegetative detritus was taken from a previous study in North America (Rogge et al., 1993b).
Zhang (2006) measured the chemical speciation of organic matter in $\mathrm{PM}_{2.5}$ emitted from four types of gasoline vehicle (light duty, heavy duty with electronic fuel injection and three-way catalyst, heavy duty with carburetor and three-way catalyst, and heavy duty carburetor), two types of diesel vehicle (light duty and heavy duty), and motorcycles. The average source profiles of diesel/gasoline vehicle exhausts used in the CMB model in the present study were calculated using the $\mathrm{PM}_{2.5}$ emission weighted averaging method, based on the $\mathrm{PM}_{2.5}$ emission factors, vehicle numbers, and annual average travel distance of the seven groups of vehicles in Beijing. According to the Beijing Statistic Yearbook (Beijing Municipal Bureau of Statistics and Beijing General Team of Investigation under the NBS, 2006), about 0.265 million motorcycles and 2.146 million cars and trucks ( 0.177 million trucks and 1.883 million passenger cars) were in Beijing in 2005. The proportion and annual average travel distance for gasoline/diesel vehicles with different scales were adopted from previous studies (Hu et al., 2002; Song and Xie, 2006). The results of weighting factors for the $\mathrm{PM}_{2.5}$ emission of different vehicle exhausts are shown in Table 1.

With regard to source profiles of straw/wood combustion, Zhang (2006) and Zhang et al. (2007) measured the chemical components in the emissions of three major types cereal straw (wheat, corn, and rice) in China and two types of wood (pine and mixed wood). In this study, the weighting factors for $\mathrm{PM}_{2.5}$ emissions of different cereal straws were calculated based on the total straw yield, the percentage of cereal disposed of by open fire in China, and the emission factors of $\mathrm{PM}_{2.5}$ in straw combustion reported previously (Gao et al., 2002; Zhu et al., 2005). The results are shown in Table 2. The source profile of wood combustion used here was an average of the emission of pine and mixed wood combustion.

Note that chemical compositions emitted only from residential coal burning (Zhang et al., 2008) were adopted as the source profile of coal burning, while chemical compositions 
Table 2. Weighting factors for the emission of $\mathrm{PM}_{2.5}$ from different straw combustion.

\begin{tabular}{lllll}
\hline Types & Straw yield ${ }^{\mathrm{a}}\left(10^{4} \mathrm{t}\right)$ & $\begin{array}{l}\text { Percent of straw dis- } \\
\text { posed by fire }{ }^{a}(\%)\end{array}$ & $\begin{array}{l}\text { Emission factor }{ }^{\mathrm{b}}(\mathrm{g} / \mathrm{kg} \\
\text { straw })\end{array}$ & Weighting factors \\
\hline wheat & 11976.3 & 9 & 59.75 & 0.412 \\
corn & 13222.6 & 5.4 & 53.45 & 0.244 \\
rice & 17522.1 & 7.8 & 39.3 & 0.344 \\
\hline
\end{tabular}

a data from Gao et al. (2002)

$\mathrm{b}$ data from Zhu et al. (2005)

Table 3. Modified source profiles with organic tracers and EC used in the CMB model (ng/mg $\left.\mathrm{PM}_{2.5}\right)$.

\begin{tabular}{|c|c|c|c|c|c|c|c|}
\hline & $\begin{array}{l}\text { Gasoline } \\
\text { Car }\end{array}$ & Diesel Car & $\begin{array}{l}\text { Residential } \\
\text { Coal }\end{array}$ & Straw & Wood & $\begin{array}{l}\text { Chinese } \\
\text { cooking }\end{array}$ & $\begin{array}{l}\text { Vegetative } \\
\text { detritus }\end{array}$ \\
\hline$n$-hexacosane & 770 & 624 & 729 & 41.7 & 48.8 & 52.0 & 109 \\
\hline$n$-heptacosane & 601 & 283 & 498 & 244 & 54.7 & 126 & 929 \\
\hline$n$-octacosane & 464 & 196 & 199 & 45.6 & 16.1 & 31.2 & 282 \\
\hline$n$-nonacosane & 392 & 81.6 & 139 & 834 & 17.6 & 304 & 6290 \\
\hline$n$-triacontane & 274 & 25.3 & 73.0 & 40.1 & 7.4 & 13.8 & 440 \\
\hline$n$-hentriacontane & 215 & 2.4 & 58.7 & 739 & 17.1 & 402 & 9440 \\
\hline$n$-dotriacontane & 130 & 0.0 & 17.4 & 17.0 & 0.0 & 0.0 & 820 \\
\hline$n$-tritriacontane & 102 & 0.0 & 17.8 & 187 & 16.8 & 53.0 & 5060 \\
\hline$n$-hexadecanoic acid & 1101 & 171 & 1436 & 4356 & 1526 & 23170 & 713 \\
\hline$n$-heptadecanoic acid & 32.9 & 29.4 & 56.4 & 121 & 64.9 & 210 & 17.4 \\
\hline$n$-octadecanoic acid & 423 & 88.6 & 423 & 1018 & 335 & 5038 & 206 \\
\hline$n$-eicosanoic acid & 20.7 & 9.6 & 50.7 & 476 & 125 & 318 & 436 \\
\hline$n$-docosanoic acid & 16.7 & 2.5 & 67.5 & 858 & 780 & 342 & 182 \\
\hline benzo[e]pyrene & 34.4 & 24.6 & 1037 & 19.5 & 297 & 10.0 & 0.0 \\
\hline benzo[ghi]perylene & 109 & 21.6 & 644 & 18.5 & 334 & 32.8 & 0.0 \\
\hline coronene & 47.4 & 1.6 & 121 & 6.8 & 97.0 & 36.3 & 0.0 \\
\hline $\begin{array}{l}17 \beta(\mathrm{H}), 21 \alpha(\mathrm{H})-30- \\
\text { norhopane }\end{array}$ & 227 & 147 & 351 & 0.0 & 0.0 & 0.0 & 0.0 \\
\hline $\begin{array}{l}17 \alpha(\mathrm{H}), 21 \beta(\mathrm{H})- \\
\text { hopane }\end{array}$ & 331 & 194 & 166 & 0.0 & 0.0 & 0.0 & 0.0 \\
\hline $\begin{array}{l}22 \mathrm{~S}-17 \alpha(\mathrm{H}), 21 \beta(\mathrm{H})- \\
\text { homohopane }\end{array}$ & 84.9 & 39.6 & 33.3 & 0.0 & 0.0 & 0.0 & 0.0 \\
\hline $\begin{array}{l}22 \mathrm{R}-17 \alpha(\mathrm{H}), 21 \beta(\mathrm{H})- \\
\text { homohopane }\end{array}$ & 65.8 & 21.4 & 50.9 & 0.0 & 0.0 & 0.0 & 0.0 \\
\hline $\begin{array}{l}22 \mathrm{~S}-17 \alpha(\mathrm{H}), 21 \beta(\mathrm{H})- \\
\text { bishomohopane }\end{array}$ & 53.8 & 19.8 & 3.7 & 0.0 & 0.0 & 0.0 & 0.0 \\
\hline levoglucosan & 33.5 & 0.0 & 315 & 14660 & 17350 & 346 & 0.0 \\
\hline cholesterol & 77.5 & 1.6 & 43.9 & 92.3 & 25.6 & 307 & 0.0 \\
\hline campesterol & 0.0 & 0.0 & 0.0 & 2302 & 41.7 & 0.0 & 0.0 \\
\hline $\mathrm{OC}$ & $3.8 \mathrm{E}+05$ & $5.8 \mathrm{E}+05$ & $4.5 \mathrm{E}+05$ & $5.2 \mathrm{E}+05$ & $3.0 \mathrm{E}+05$ & $8.4 \mathrm{E}+05$ & $3.2 \mathrm{E}+05$ \\
\hline $\mathrm{EC}$ & $3.9 \mathrm{E}+04$ & $1.6 \mathrm{E}+05$ & $1.2 \mathrm{E}+05$ & $4.6 \mathrm{E}+04$ & $1.6 \mathrm{E}+05$ & $1.5 \mathrm{E}+04$ & $9.4 \mathrm{E}+03$ \\
\hline
\end{tabular}

from Chinese cooking obtained from Zhao et al. (2007) were used as a source profile of cooking in this study. Therefore the source profiles of the fitting species for the CMB model run were listed in Table 3.

\section{Results and discussion}

\subsection{Variations in $\mathrm{PM}_{2.5}$ and $\mathrm{OC} / \mathrm{EC}$ concentrations}

The seasonal variations in the mass concentrations of $\mathrm{PM}_{2.5}$ and $\mathrm{OC} / \mathrm{EC}$ are presented in Fig. 1. During the measurement period, the $\mathrm{PM}_{2.5}$ mass concentrations varied from $20.6 \mu \mathrm{g} / \mathrm{m}^{3}$ to $487.3 \mu \mathrm{g} / \mathrm{m}^{3}$, with averages of $83.3 \mu \mathrm{g} / \mathrm{m}^{3}$ in summer and $127.7 \mu \mathrm{g} / \mathrm{m}^{3}$ in winter. The average OC and EC 


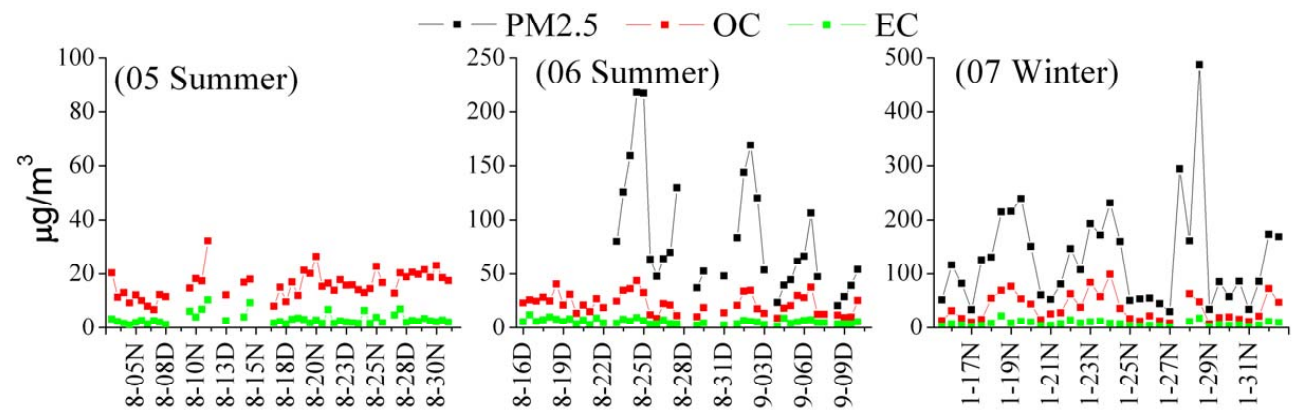

Fig. 1. Time series for mass concentrations of $\mathrm{PM}_{2.5}$ and OC/EC in Beijing.

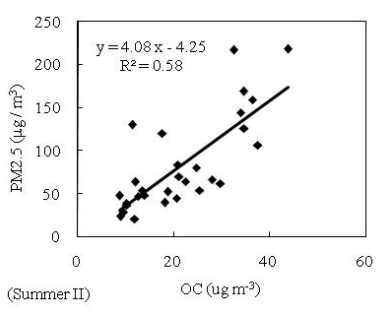

(a)

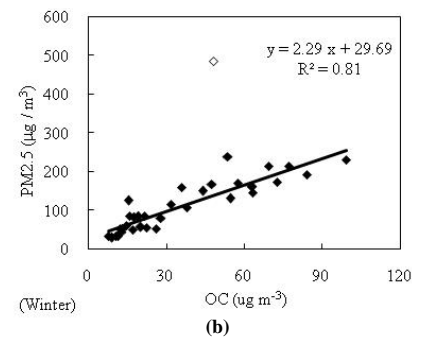

Fig. 2. Correlations between $\mathrm{OC}$ and $\mathrm{PM}_{2.5}$ concentrations (Summer II: Aug.-Sep. 2006; Winter: Jan.-Feb. 2007).

concentrations in $\mathrm{PM}_{2.5}$ were 16.1 and $3.2 \mu \mathrm{g} / \mathrm{m}^{3}, 22.1$ and $5.5 \mu \mathrm{g} / \mathrm{m}^{3}$, and 36.2 and $7.4 \mu \mathrm{g} / \mathrm{m}^{3}$ in Summer I, Summer II, and Winter, respectively. OC accounted for about $8.7-57.5 \%$ of the $\mathrm{PM}_{2.5}$ concentrations, with an average of $30.3 \%$. The concentrations of $\mathrm{OC}, \mathrm{EC}$, and $\mathrm{PM}_{2.5}$ in winter, were 1.3-2.3 times as high as those in summer, which may have been due to larger amounts of emission and more unfavorable dispersion conditions in winter.

The prevailing wind direction was from the northwest in both summer and winter. Wind speeds varied from 0.01 to $8.0 \mathrm{~m} / \mathrm{s}$ in summer, and were lower than $0.5 \mathrm{~m} / \mathrm{s}$ for $35 \%$ of the time. Although wind speeds in winter varied over a similar range, from 0.02 to $9.0 \mathrm{~m} / \mathrm{s}$, the frequency of static conditions with wind speed lower than $0.5 \mathrm{~m} / \mathrm{s}$ was much higher, about $47.1 \%$. However, the frequency of high wind speed $(>5 \mathrm{~m} / \mathrm{s})$ in winter $(5.1 \%)$ was twice that in summer (2.5\%). A negative correlation between wind speed and $\mathrm{PM}_{2.5}$ concentration was observed during the observation period, as high wind speed generally favored the diffusion of air pollutants. $\mathrm{PM}_{2.5}$ concentrations were very low (20.6$39.1 \mu \mathrm{g} / \mathrm{m}^{3}$ ) when the wind speed rose to more than $5 \mathrm{~m} / \mathrm{s}$ on 8-9 September 2006. In winter, the $\mathrm{PM}_{2.5}$ concentrations decreased significantly from $160 \mu \mathrm{g} / \mathrm{m}^{3}$ to $50 \mu \mathrm{g} / \mathrm{m}^{3}$ on $25-27$ January 2007, when wind speeds increased to about $5.0 \mathrm{~m} / \mathrm{s}$. However, when the wind speeds exceeded $5 \mathrm{~m} / \mathrm{s}$, no marked decreases were observed in $\mathrm{PM}_{2.5}$ concentrations, and sometimes sharp increases were observed. For example, the highest wind speed of $9.0 \mathrm{~m} / \mathrm{s}$ occurred during the day on 29 Jan- uary 2007 , when an abnormally high average $\mathrm{PM}_{2.5}$ concentration of $487.3 \mu \mathrm{g} / \mathrm{m}^{3}$ was observed with a low percentage of OC $(10 \%)$. As another example, the average $\mathrm{PM}_{2.5}$ concentration of $86.1 \mu \mathrm{g} / \mathrm{m}^{3}$, with a low percentage of OC at $18 \%$, was observed during the day on 31 January 2007 , when the highest wind speed during that time was $6.7 \mathrm{~m} / \mathrm{s}$. The low OC contents under both conditions suggested that the increase in $\mathrm{PM}_{2.5}$ concentration may have been due to fugitive dust containing less OC than other sources suspended by the strong winds. The different influence of strong winds on $\mathrm{PM}_{2.5}$ concentrations could be explained by the distinct land vegetation coverage and relative humidity between summer and winter; both dry weather and bare surface (especially bare farmland) in winter in Beijing facilitate the emission of fugitive dust.

The variation between $\mathrm{PM}_{2.5}$ and $\mathrm{OC}$ concentrations were quite similar, with correlation coefficients $\left(R^{2}\right)$ of 0.58 in summer and up to 0.81 in winter if the sample collected during the day on 29 January 2007 was excluded [the white dot in Fig. 2 (winter)]. The average OC/EC ratio was about 5.1, which was slightly smaller than the value of 7.0 in 2000 in Beijing reported by Zheng et al. (2005), but higher than the values of 3.8 in January 2004 and 2.6 in August 2004 in Beijing reported by Song et al. (2007).

\subsection{Concentrations of major organic species}

In total, 114 organic compounds were quantified and grouped into 12 classes. The sum of the concentrations of these compounds accounted for about $3 \%$ of the total organic matter in $\mathrm{PM}_{2.5}$ in summer and $6 \%$ in winter. The contributions of each class are shown in Fig. 3. The dominant compounds in summer were $n$-alkanoic acids, followed by dicarboxylic acids and sugars. In contrast, sugars were the most abundant components in winter, followed by PAHs, $n$-alkanes, and $n$-alkanoic acids. Generally, $n$-alkanoic acids could be detected in most sources, among which cooking emissions were important with no clear seasonal differences in source intensity (Rogge et al., 1991). Sugars were mainly emitted from biomass burning and were verified to be reliable tracers of biomass burning (Simoneit, 1986, 2002; Simoneit and 


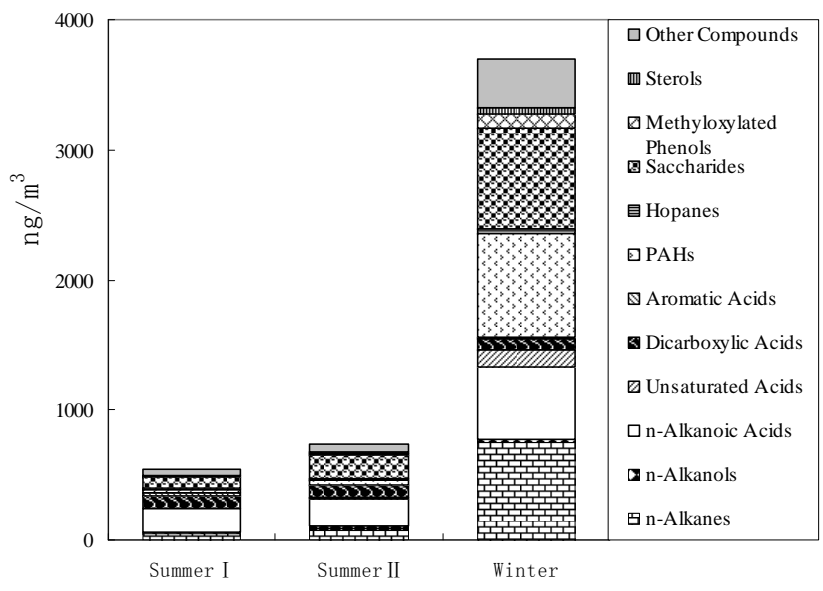

Fig. 3. Chemical compositions of organic compounds in $\mathrm{PM}_{2.5}$ in Beijing (Summer I: Aug. 2005; Summer II: Aug.-Sep. 2006; Winter: Jan.-Feb. 2007).
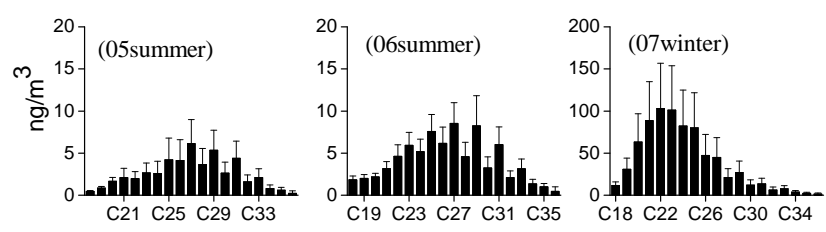

Fig. 4. Ambient concentrations and distribution of $n$-alkanes in $\mathrm{PM}_{2.5}$ in Beijing.

Elias, 2000, 2001; Schauer et al., 2001; Zhang et al., 2007). Dicarboxylic acids could be generated through photochemical reaction in the atmosphere, and their concentrations were closely related to atmospheric photochemical activity.

\section{(1) $n$-Alkanes}

Normal alkanes from $\mathrm{C} 18$ to $\mathrm{C} 36$ were measured in this study (Fig. 4). All the $n$-alkanes showed a strong seasonal variation, with lower total concentrations in summer (average: 48 and $73 \mathrm{ng} / \mathrm{m}^{3}$ in Summer I and Summer II, respectively) and much higher concentrations in winter (average: $748 \mathrm{ng} / \mathrm{m}^{3}$ ). Although many emission sources of airborne $n$-alkanes exist, including both biogenic and anthropogenic sources, the relative distributions of $n$-alkanes can provide source information. Previous studies showed that the $n$-alkanes emitted from biogenic sources, such as biomass burning, vegetative detritus, and cooking, had a unique odd carbon number preference, with the maximum concentration species (Cmax) at C29, C31, or C33 (Rogge et al., 1993b; Zhang et al., 2007; Zhao et al., 2007), while $n$-alkanes with lower carbon numbers were usually attributable to the emission of fossil fuel (Rogge et al., 1993a; Schauer et al., 1999a, 2002). The predominant $n$-alkanes emitted were slightly different between coal combustion (dominated by $n$-docosane, $n$-tricosane, and $n$-pentacosane) and vehicle exhausts (dominated by $n$-eicosane and $n$-heneicosane) (Schauer et al., 1999a; Zhang, 2006; Zhang et al., 2008). In this study, the distribution of $n$-alkanes showed obvious seasonal characteristics: Cmax appeared at C27 and C29 in summer and at C22 and $\mathrm{C} 23$ in winter. Meanwhile, a strong odd carbon number preference was observed for higher $n$-alkanes $(\geq \mathrm{C} 27)$ in both summer and winter, indicating their origin from biogenic sources. CPI (carbon predominance index) values were 1.8, 2.0 and 1.7 in Summer I, Summer II and winter, respectively.

$$
\mathrm{CPI}=\frac{\sum_{i=13}^{17} C_{2 i+1}}{2}\left[\frac{1}{\sum_{i=13}^{17} C_{2 i}}+\frac{1}{\sum_{i=14}^{18} C_{2 i}}\right]
$$

The seasonal variation in $n$-alkane distribution was reported to be due to the volatility of low-molecular-weight $n$ alkanes (C18-C26) and the temperature difference between winter and summer. Compared to the conditions in summer, the low temperature in winter favors the conversion of lowercarbon-number $n$-alkanes from the gas phase to the particulate phase, which partly facilitates the overwhelming concentrations of $n$-alkanes with lower carbon numbers (Feng et al., 2005; He et al., 2006; Huang et al., 2006). The Cmax appearing at $\mathrm{C} 22$ and $\mathrm{C} 23$ in winter also implied a significant contribution of coal burning.

\section{(2) Sugars}

Three types of sugar were quantified: levoglucosan, galactosan, and mannosan. The seasonal variations in their concentrations were similar to those of $n$-alkanes, i.e., high in winter (average: $772 \mathrm{ng} / \mathrm{m}^{3}$ ) and low in summer (average: 94 and $191 \mathrm{ng} / \mathrm{m}^{3}$ in Summer I and Summer II, respectively). Of these, levoglucosan showed the highest concentrations, with averages of $82 \mathrm{ng} / \mathrm{m}^{3}, 167 \mathrm{ng} / \mathrm{m}^{3}$, and $678 \mathrm{ng} / \mathrm{m}^{3}$ in Summer I, Summer II, and Winter, respectively. The concentrations of levoglucosan recorded here were much higher than the levels in summer $\left(34 \mathrm{ng} / \mathrm{m}^{3}\right)$, autumn $\left(117 \mathrm{ng} / \mathrm{m}^{3}\right)$, and winter $\left(78 \mathrm{ng} / \mathrm{m}^{3}\right)$ from 2002 to 2003 in Beijing (He et al., 2006), but much lower than the level of $3048 \mathrm{ng} / \mathrm{m}^{3}$ measured at urban sites in California in the United States during episodes of severe winter air pollution (Schauer and Cass, 2000). The source indication of levoglucosan concentrations will be discussed in detail in Sect. 3.3.

\section{(3) Sterols}

Four sterols were detected in this study: campesterol, cholesterol, $\beta$-sitosterol, and stigmasterol (Fig. 5). The seasonal trends in total concentrations were also similar to those of the $n$-alkanes, i.e., higher in winter (average: $49 \mathrm{ng} / \mathrm{m}^{3}$ ) and 


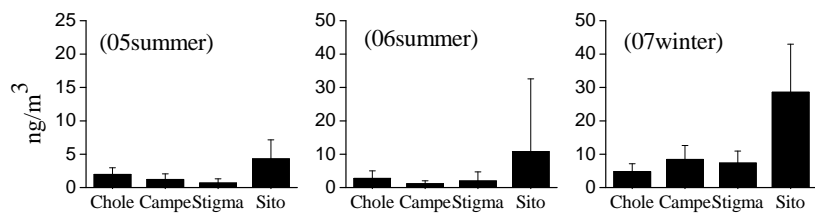

Fig. 5. Ambient concentrations of sterols in Beijing (Chole: cholesterol; Campe: campesterol; Stigma: stigmasterol; Sito: $\beta$ sitosterol).

lower in summer (average: 8 and $17 \mathrm{ng} / \mathrm{m}^{3}$ in Summer I and Summer II, respectively). Of these, $\beta$-sitosterol showed the highest concentrations, accounting for almost half of the concentrations of total sterols. Compared to the other three sterols of vegetable origin, the concentrations of cholesterol were relatively constant in both summer and winter; the concentrations in winter were approximately double those in summer, while concentrations of the other sterols were twoto tenfold higher in winter than in summer. Previous studies have shown that cholesterol is typical in the sources related to high-temperature processing of animal tissues, such as emissions from charbroilers, meat cooking, and Chinese cooking (Rogge et al., 1991; Zhao et al., 2007). These observations imply a stable impact of cooking emissions on ambient organic aerosols, consistent with the constant concentrations of fatty acids, which are also possible organic tracers of cooking emissions.

\section{(4) Hopanes}

Seven hopanes were analyzed and quantified in this study: $\quad 17 \alpha(\mathrm{H})-22,29,30$-trisnorhopane $(\mathrm{Tm}), \quad 17 \beta(\mathrm{H})$ $21 \alpha(\mathrm{H})$-30-norhopane (HP29), $17 \alpha(\mathrm{H}), \quad 21 \beta(\mathrm{H})$-hopane (HP30), 22R-17 $\alpha(\mathrm{H}), \quad 21 \beta(\mathrm{H})$-homohopane (HP31R), $22 \mathrm{~S}-17 \alpha(\mathrm{H}), 21 \beta(\mathrm{H})$-homohopane (HP31S), 22S-17 $\alpha(\mathrm{H})$, $21 \beta(\mathrm{H})$-bishomohopane (HP32S), and $22 \mathrm{R}-17 \alpha(\mathrm{H})$, $21 \beta(\mathrm{H})$-bishomohopane (HP32R). Hopanes are a series of pentacyclic triterpenoids, which are considered as organic tracers for fossil fuel combustion. Their fingerprint distribution could even indicate the maturity of fossil fuels and their emissions (Oros and Simoneit, 2000; Zhang et al., 2008). For example, almost all the Chinese coal combustion (except industrial bituminite) emitted HP29 as a dominant compound, while the predominant hopane in vehicle exhausts was HP30 (Zhang et al., 2008). In addition, Tm usually showed higher concentrations in the emission of coal combustion than in vehicle exhausts (Zhang et al., 2008). The homohopane index $\{\mathrm{C} 31[\mathrm{~S} /(\mathrm{S}+\mathrm{R})]\}$ also increased along with the increasing rank of fuel maturity (Oros and Simoneit, 2000; Schnelle-Kreis et al., 2007). In this study, the distribution of the ambient hopane series showed a distinct seasonal variation (Fig. 6); HP29 showed the highest concentrations, followed by HP30 and Tm in

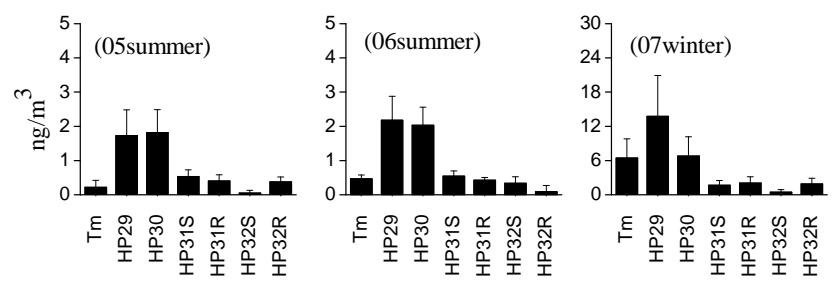

Fig. 6. Distributions of the hopane series in ambient aerosol in Beijing (Tm: $17 \alpha(\mathrm{H})-22,29,30$-trisnorhopane; HP29: $17 \beta(\mathrm{H})-$ 21 $\alpha(\mathrm{H})$-30-norhopane; HP30: $17 \alpha(\mathrm{H}), 21 \beta(\mathrm{H})$-hopane; HP31R: $22 \mathrm{R}-17 \alpha(\mathrm{H}), 21 \beta(\mathrm{H})$-homohopane; HP31S: $22 \mathrm{~S}-17 \alpha(\mathrm{H}), 21 \beta(\mathrm{H})-$ homohopane; HP32S: 22S-17 $\alpha(\mathrm{H}), 21 \beta(\mathrm{H})$-bishomohopane; HP32R: 22R-17 $\alpha(\mathrm{H}), 21 \beta(\mathrm{H})$-bishomohopane).

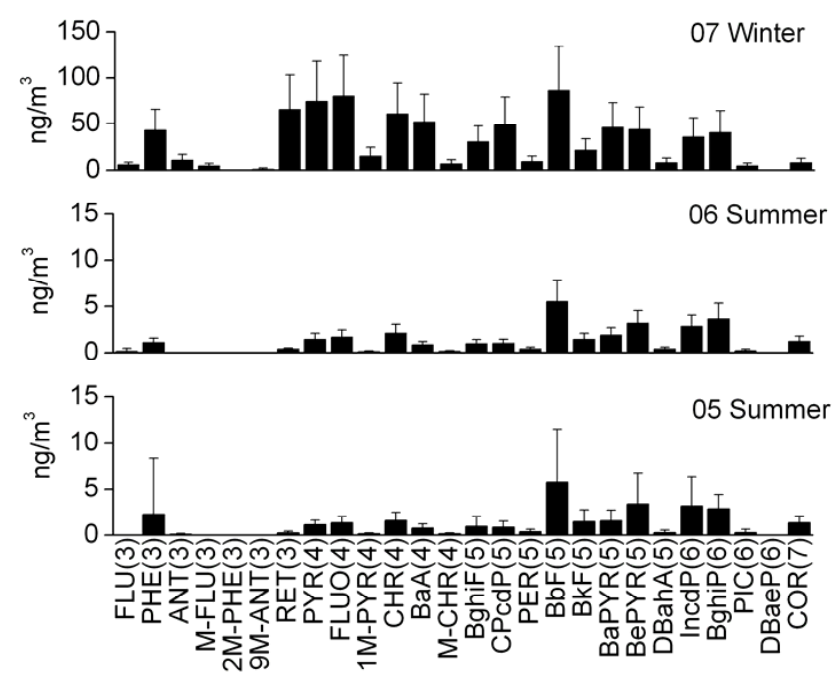

Fig. 7. mbient concentrations of PAH in Beijing (digits in parentheses indicate the ring numbers in the molecular structure of $\mathrm{PAH}$ : FLU, Fluoranthene; PHE, Phenanthrene; ANT, Anthracene; MFLU, Methyl-fluorene; M-PHE, Methyl-Phenanthrene; M-ANT, Methyl-Anthracene; RET, Retene; PYR, Pyrene; CHR, Chrysene; $\mathrm{BaA}$, Benzo[a]anthracene; M-CHR, Methyl-Chrysene; BghiF, Benzo[ghi]fluoranthene; CPcdp, Cyclopenta[cd]pyrene; PER, Perylene; BbF, Benzo[b]fluoranthene; BkF, Benzo[k]fluoranthene; BaPYR, Benzo[a]pyrene; BePYR, Benzo[e]pyrene; DBahA, Dibenzo[a,h]anthracene; IncdP, Indeno[1,2,3-cd]pyrene; BghiP, Benzo[ghi]perylene; PIC, Picene; DBaeP, Dibenz[a,e]pyrene; COR, Coronene).

winter, while the concentrations of HP29 and HP30 were similar in summer. The ratio of Tm vs. HP30 increased from 0.1 to 0.2 in summer to 0.9 in winter. The homohopane index was about 0.6 in summer and 0.5 in winter. These observations indicated that the contribution of coal burning rise markedly from summer to winter in Beijing. 
Table 4. Comparison of source contribution (\%) to ambient fine organic carbon concentrations in Beijing.

\begin{tabular}{llllll}
\hline Source & \multicolumn{2}{c}{ Zheng et al. (2005) } & \multicolumn{2}{c}{ This study } \\
\hline & Jul & Jan & Aug & Aug-Sep & Jan-Feb \\
& 2000 & 2000 & 2005 & 2006 & 2007 \\
Gasoline vehicles & 19.0 & 9.9 & $10.6 \pm 2.8$ & $7.1 \pm 1.5$ & $11.9 \pm 0.8$ \\
\hline $\begin{array}{l}\text { Diesel vehicles } \\
\text { Vegetative detritus }\end{array}$ & 1.5 & & $9.6 \pm 6.2$ & $5.7 \pm 1.5$ & $5.2 \pm 4.2$ \\
dust & 25.6 & 7.2 & $0.3 \pm 0.2$ & $0.3 \pm 0.2$ & $0.5 \pm 0.1$ \\
Wood combustion & & 14.5 & $10.4 \pm 3.5$ & $8.2 \pm 2.0$ & $23.2 \pm 5.0$ \\
Straw combustion & & 13.8 & $1.3 \pm 0.7$ & $1.7 \pm 2.8$ & $2.9 \pm 0.6$ \\
Coal smoke & 5.8 & 2.4 & $2.1 \pm 2.2$ & $1.8 \pm 0.8$ & $17.2 \pm 2.7$ \\
Cigarette & 2.2 & & $24.5 \pm 4.2$ & $23.8 \pm 4.3$ & $17.3 \pm 3.0$ \\
Cooking & & 52.1 & $41.1 \pm 9.7$ & $51.4 \pm 5.6$ & $21.9 \pm 8.6$ \\
Other OC & 45.9 & & &
\end{tabular}

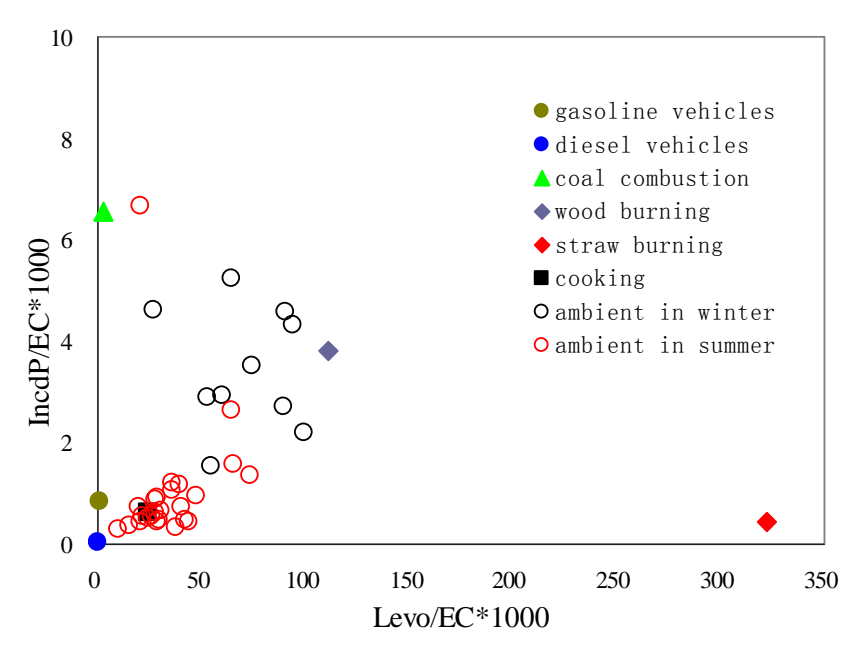

Fig. 8. Ratio-ratio plots of ambient samples and source profiles (Levo, levoglucosan; IncdP, Indeno[1,2,3-cd]pyrene).

\section{(5) PAHs}

PAHs are formed through incomplete combustion of organic substances, partly from natural combustion such as volcanic activity and forest fires, but with the majority due to anthropogenic emissions (Ravindra et al., 2008). Considering their toxicity and carcinogenicity, ambient PAH concentrations are a cause for concern and have attracted a great deal of attention. In total, 26 PAHs were identified in this study (Fig. 7). The average concentrations of all PAHs were $30.0 \mathrm{ng} / \mathrm{m}^{3}$, $31.3 \mathrm{ng} / \mathrm{m}^{3}$, and $808.7 \mathrm{ng} / \mathrm{m}^{3}$ in Summer I, Summer II, and Winter, respectively. The PAH distribution showed seasonal differences. The dominant PAHs in summer were those with a 5-ring structure, accounting for about $50 \%$ of the total PAHs, followed by 4-ring PAHs (20\%) and 6-ring PAHs (20\%), with 3-ring PAHs accounting for only 6-9\% of the total. In contrast, 4- and 5-ring PAHs accounted for about
$36 \%$ and $37 \%$ of the total PAHs in winter, respectively, followed by 3-ring PAHs (16\%). This seasonal variation could be attributed to the effect of ambient temperature, due to the volatility of PAH with molecular weight $\leq 252$.

Three source-specific and stable species were selected to construct ratio-ratio plots (Fig. 8): levoglucosan (Levo), indeno[1,2,3-cd]pyrene (IncdP), and EC. The concentrations of Levo and IncdP were normalized relative to EC as a reference compound. Ambient data and source profiles used in this study are shown on ratio-ratio plots. The results clearly showed that biomass burning, especially the burning of straw, yielded a much higher ratio of Levo/EC than other sources, while coal combustion had the highest ratio of IncdP/EC. The ratios of both IncdP/EC and Levo/EC in ambient samples displayed seasonal differences. In most cases, the ratios of In$\mathrm{cdP} / \mathrm{EC}$ in ambient samples in summer were between those in gasoline and diesel vehicle exhausts, and increased sharply to approach the ratio of coal combustion in winter, implying a significant contribution of coal combustion in winter. Ambient ratios of Levo/EC in summer were similar to those of cooking emissions, and some were slightly higher than those of other sources, except biomass burning, indicating the influence of biomass burning to some degree in summer. Those ambient ratios also increased markedly in winter and approached those of wood burning, indicating a strong impact of biomass burning.

\subsection{Source apportionment}

Organic tracers as well as EC were applied to quantify the contributions of various sources to ambient carbonaceous components in $\mathrm{PM}_{2.5}$ in Beijing. Seven types of source were considered in the model: gasoline and diesel vehicle exhaust, wood and straw combustion, coal burning, cooking, and vegetative detritus. Eleven, five, and seven samples were used in the CMB model for the Summer I, 
Table 5. Comparison of source contribution (\%) to ambient $\mathrm{PM}_{2.5}$ in Beijing by different studies.

\begin{tabular}{|c|c|c|c|c|c|c|c|}
\hline \multirow[t]{2}{*}{ Source } & \multicolumn{2}{|c|}{ Zheng et al. (2005) } & \multirow{2}{*}{$\begin{array}{l}\begin{array}{l}\text { Song et } \\
\text { al. (2006) }\end{array} \\
\text { annual }\end{array}$} & \multicolumn{2}{|c|}{ Song et al. (2007) } & \multicolumn{2}{|c|}{ This study } \\
\hline & Jul & Jan & & Aug & Jan & Aug-Sep & Jan-Feb \\
\hline & 2000 & 2000 & 2000 & 2004 & 2004 & 2006 & 2007 \\
\hline Gasoline vehicles & & & & & & $5.0 \pm 2.6$ & $9.3 \pm 2.4$ \\
\hline Diesel vehicles & 7.4 & 4.5 & 6.0 & 4.5 & 7.9 & $2.5 \pm 1.2$ & $2.4 \pm 1.5$ \\
\hline Vegetative detritus & 0.8 & & & & & $0.2 \pm 0.2$ & $0.5 \pm 0.1$ \\
\hline dust & 32.9 & 21.2 & 6.0 & 14.0 & 5.9 & & \\
\hline Wood combustion & & 7.4 & 11.0 & 17.3 & 17.9 & $7.4 \pm 2.0$ & $23.2 \pm 7.2$ \\
\hline Straw combustion & & & & & & $1.0 \pm 1.3$ & $1.7 \pm 0.7$ \\
\hline Coal smoke & 2.9 & 15.7 & 19.0 & 12.5 & 37.9 & $1.2 \pm 0.8$ & $11.5 \pm 4.0$ \\
\hline Cigarette & 0.6 & 1.5 & & & & & \\
\hline Chinese cooking & & & & & & $7.4 \pm 3.5$ & $6.2 \pm 1.9$ \\
\hline
\end{tabular}

Summer II, and Winter periods, respectively. The average $R^{2}, \chi^{2}, \mathrm{DF}$, and percentage of aerosol mass explained in the results using this model were $0.95 \pm 0.01,2.46 \pm 0.98,15 \pm 1$, and $63.77 \pm 15.02 \%(n=23)$, respectively, while the average $\mathrm{C} / \mathrm{M}$ ratio and average absolute $\mathrm{R} / \mathrm{U}$ ratio were $0.98 \pm 0.26$ and $0.98 \pm 0.85(n=490)$, respectively.

The source apportionment results of fine OC are shown in Table 4 along with previously reported results (Zheng et al., 2005). This study found that biomass burning (straw and wood) showed the highest contribution to fine particulate OC in winter, followed by coal burning, vehicle exhaust (gasoline and diesel), and cooking. In contrast, the contribution from cooking became highest, followed by vehicle exhaust and biomass combustion, while coal burning had little influence on ambient $\mathrm{OC}$ in summer.

\section{(1) Biomass burning}

Biomass burning was estimated to be one of the most important sources of particulate organic matter in Beijing, although it is thought to be less important in China overall (Wang et al., 2007). In fact, agricultural production in China led to a yield of about 593 million tons of straw in 2003, about $23 \%$ of which was disposed of in open fires (Cao et al., 2007). In addition, straw and firewood were estimated to provide $18.4 \%$ and $14.3 \%$, respectively, of the energy consumption in rural areas of China in 2000; most of the straw and wood was used domestically and accounted for about $55.2 \%$ of household energy consumption (Wang and Feng, 2004). Although the proportion of agricultural waste destroyed by open burning could be considered to be zero due to strict control in Beijing (Cao et al., 2005), the air quality may also be influenced by open fires of agricultural waste in nearby provinces of Hebei and Tianjin. The Environmental Protection Bureau reported that the ambient concentra- tions of pollutants exceeded the air quality standards on 2 days in June 2005 due to straw burning in open fields in areas close to Beijing (http://news.sina.com.cn/c/2008-05-05/ 021513829040s.shtml). The amounts of straw and wood consumed as domestic fuel in rural areas of Beijing in 2005 were equivalent to about 0.59 and 0.25 million tons of standard coal, respectively (China Energy Yearbook Editorial Committee, 2005/2006).

In this study, biomass burning was estimated to account for about $26 \%$ and $11 \%$ of the ambient OC in winter and summer, respectively. Wood smoke was also distinguished from straw burning. The average amounts of $\mathrm{OC}$ originating from wood smoke were approximately $2.1 \mu \mathrm{g} / \mathrm{m}^{3}(10 \%)$ in summer and $11.3 \mu \mathrm{g} / \mathrm{m}^{3}(23 \%)$ in winter, and those from straw burning were $0.4 \mu \mathrm{g} / \mathrm{m}^{3}(2 \%)$ in summer and $1.4 \mu \mathrm{g} / \mathrm{m}^{3}(3 \%)$ in winter. The relative contribution of straw was much smaller than that of wood smoke, which was the opposite of their consumption. This can be explained by differences between the $\mathrm{PM}_{2.5}$ sampling times in this study and the harvest times of the main crops in Beijing; wheat and maize were harvested in June and in the fall, respectively, and both were missing from our sampling periods. In comparison with the CMB results of a previous study in Beijing (Zheng et al., 2005), the contribution of wood combustion in the present study was much higher, although Zheng et al. (2005) also concluded that wood combustion had the greatest contribution in winter. The contribution of wood combustion in summer was approximately $11 \%$ in this study, but was not identified in the previous study by Zheng et al. (2005).

Furthermore, the source contributions to ambient $\mathrm{PM}_{2.5}$ in Summer II and Winter were also calculated from the results of fine $\mathrm{OC}$ and the ratios of fine $\mathrm{OC}$ to $\mathrm{PM}_{2.5}$ emitted from primary sources. The results are listed in Table 5, together with the CMB results of Zheng et al. (2005) and positive matrix factorization (PMF) results of Song et al. (2006) 
and Song et al. (2007). The contribution of biomass burning to ambient $\mathrm{PM}_{2.5}$ in Beijing increased from $11 \%$ in 2000 to $18 \%$ in 2004 in the PMF results, indicating changes in pollution conditions. The annual average of biomass contribution to $\mathrm{PM}_{2.5}(17 \%)$ in this study was similar to that $(18 \%)$ in the PMF results in Beijing in 2004 (Song et al., 2007), and higher than the two other sets of results in Beijing in 2000.

In previous studies, levoglucosan was considered a key tracer in estimating the influence of biomass burning on the ambient air quality (Simoneit, 1986, 2002; Simoneit and Elias, 2000, 2001; Schauer et al., 2001; Zhang et al., 2007). Schauer et al. (2001) estimated the contributions of wood burning to the ambient concentrations of volatile OC ranging from $5.0 \%$ to $24.0 \%$ in Fresno, California, USA, using levoglucosan as a tracer of wood burning. Wang et al. (2007) also used levoglucosan to estimate the contributions of biomass burning to $\mathrm{PM}_{2.5}$ concentrations (about 3.0$19.0 \%$ ) in Guangzhou, China. In the present study, the average ambient ratios of levoglucosan to OC were $0.6 \%$ in summer and $1.4 \%$ in winter. The average levoglucosan to OC ratios in emissions of wood burning and cereal burning in China were 5.9\% and 2.8\%, respectively (Zhang, 2006; Zhang et al., 2007). Given that all levoglucosan was emitted from wood burning and the use of a method similar to that described by Wang et al. (2007), the contributions of wood burning to ambient $\mathrm{OC}$ in $\mathrm{PM}_{2.5}$ were calculated to be approximately $10 \%$ in summer and $24 \%$ in winter, which agreed quite well with our calculations using the CMB model.

\section{(2) Chinese cooking}

The composition of particles emitted from the cooking of food is strongly dependent on cooking procedure, including the materials used, cooking temperature, and cooking time. These lead to differences in source profiles of POM emitted from Chinese and Western-style cooking (Hildemann et al., 1991; Rogge et al., 1991; He et al., 2004; Zhao et al., 2007). Previous studies in the United States have indicated that the cooking of food is one of the largest sources of fine organic aerosols in urban areas, especially in major cities where millions of people must be fed several times per day. The emissions from cooking meat can contribute up to approximately $20 \%$ of the annual average concentrations of fine organic aerosols in the Los Angeles area (Hildemann et al., 1991; Schauer et al., 1996, 1999b; Cass, 1998; Schauer, 1998; Schauer and Cass, 2000). China has a very large population of around 1.3 billion, and Beijing as the capital city has a population of over 17 million. Beijing has approximately 35000 restaurants, as well as large numbers of street vendors. In 2007, restaurants accounted for $2.7 \%$ of the annual municipal GDP with an annual growth rate of $19.4 \%$. Another possible important cooking source may be from that in suburban areas by the floating population working temporarily in Beijing City.

However, only a few studies have examined the impact of cooking on ambient air quality (Huang et al., 2006; Zhao et al., 2007). The quantified contributions of cooking emissions to ambient OC estimated in the present study were about $4.0 \mu \mathrm{g} / \mathrm{m}^{3}(24.5 \%), 7.7 \mu \mathrm{g} / \mathrm{m}^{3}(23.8 \%)$, and $8.0 \mu \mathrm{g} / \mathrm{m}^{3}$ $(17.3 \%)$ in Summer I, Summer II, and Winter, respectively. The contributions from cooking did not vary greatly between seasons, comprising the largest contributor to ambient $\mathrm{OC}$ in summer (due to the reduced consumption of coal and wood) and a major source in winter. These results were in agreement with the consistently high concentrations of cholesterol and fatty acids in the ambient aerosols, which are organic tracers of cooking emissions. Note that the contribution of Chinese cooking to $\mathrm{PM}_{2.5}$ was relatively low, about $7.4 \%$ in summer and $6.2 \%$ in winter, which was because the particles emitted from cooking consisted mainly of organic matter.

Yang et al. (2005) reported a significant contribution of modern carbon originating from modern sources, such as biomass burning and restaurant emissions, to the total fine carbonaceous PM burden in Beijing in 2001, with values of $33.7 \%$ in January and $38.9 \%$ in August. In the present study, the total contributions of biomass burning and Chinese cooking to ambient OC were about $35 \pm 5 \%$ in summer and $43 \pm 5 \%$ in winter, which were similar to the results obtained by ${ }^{14} \mathrm{C}$ analysis.

\section{(3) Coal combustion}

Coal is the dominant fuel in Beijing. For example, energy consumption was 55.2 million tons standard coal equivalents in Beijing in 2005, of which 30.7 million tons (55.6\%) was coal (China Energy Yearbook Editorial Committee, $2005 / 2006$ ). Of the various usages of coal, residential coal burning can have much more adverse effects due to its higher emission factors and lower emission altitude; i.e., the average emission factors are $43.7 \%$ for OC and $9 \%$ for EC in $\mathrm{PM}_{2.5}$ emitted from residential coal burning, and about $8 \%$ for $\mathrm{OC}$ and $1.5 \%$ for $\mathrm{EC}$ in $\mathrm{PM}_{2.5}$ emitted from industrial coal burning (Zhang, 2006). Therefore, the contribution of residential coal burning to fine organic aerosols in winter (heating period) is likely to be considerable. In this study, coal burning contributed up to $17 \%$ of the ambient $\mathrm{OC}$ and $12 \%$ of the $\mathrm{PM}_{2.5}$ in winter, and fell to $2 \%$ of the $\mathrm{OC}$ and $1 \%$ of the $\mathrm{PM}_{2.5}$ in summer. Such marked differences between winter and summer are not unusual due to the much larger amounts of coal consumed in winter for heating. These observations were consistent with those based on the distribution of $n$-alkanes and hopane series and ratio-ratio plots discussed in Sect. 3.2. In comparison with the results of Zheng et al. (2005), the contribution of coal burning showed similar seasonal trends: lower in summer and higher in winter. However, the contributions in the PMF results were much higher, 
as they may have counted both residential and industrial coal burning together.

\section{(4) Vehicle exhaust}

Due to the rapid process of economic growth and urbanization, the number of civil motor vehicles in Beijing increased to 2 million in 2005, 2.4 million in 2006, and more than 3.0 million in 2007, with an annual growth rate of more than $20 \%$. The CMB results showed that the contributions of vehicle exhaust accounted for $13-20 \%$ of ambient OC and $8-12 \%$ of ambient $\mathrm{PM}_{2.5}$. There seems to be a decrease in the contributions of both gasoline vehicles and diesel vehicles from summer in 2005 to summer in 2006. This may be attributed to the implementation of a new standard for emissions from vehicles in Beijing late in 2005 (equivalent to the European emission standards for vehicles , ) (http:// news.163.com/05/1226/13/25TCSDNI0001124T.html). The relative contributions from gasoline vehicles are somewhat higher than those of diesel vehicles during the campaigns.

The annual contributions of vehicle exhaust to ambient $\mathrm{PM}_{2.5}$ determined here were higher than in previous studies. In addition to the increasing number of vehicles in Beijing, this may also be partly explained by urban road dust, which is derived from, for example, the deposition of vehicle exhaust, smoke from coal combustion, and ambient aerosols. Therefore, the contribution of vehicle exhaust in this study may have included part of the re-suspended road dust. If road dust were considered as a receptor sample, we can then do the source apportionment by using the CMB model, and found that about $21 \%$ of the $\mathrm{PM}_{2.5}$ in urban road dust originated from vehicle exhaust.

The seasonal variations in vehicular contributions reported by different researchers are quite different: Zheng et al. (2005) considered the contribution of vehicle exhaust to be higher in summer and lower in winter, while Song et al. (2007) reported opposite results. In this study, the seasonal variation in the contribution of vehicle exhausts was unclear and further investigations are required.

\section{(5) Other}

The contributions of vegetative detritus to ambient OC detected in the present study were small in both summer $(0.3 \%)$ and winter $(0.5 \%)$. The residuals of the mass concentrations that could not be explained by these seven sources, including secondary organic aerosols (SOAs), accounted for about 22$51 \%$ of the OC in Beijing and were higher in summer (average: $44 \%)$ and lower in winter $(22 \%)$. The higher residuals in summer could be explained by the higher contributions of SOAs from active photochemical processes. Lin (2007) estimated that the secondary OC could explain almost $19 \%$ of the OC in winter and $45 \%$ in summer in Beijing, which agreed well with the percentages of unexplained carbonaceous aerosols in this study. Zheng et al. (2005) also reported that the residuals of mass concentrations were higher in summer (about $45.9 \%$ ).

\section{Conclusions}

During the measurement period, the $\mathrm{PM}_{2.5}$ mass concentrations changed markedly from $20.6 \mu \mathrm{g} / \mathrm{m}^{3}$ to $487.3 \mu \mathrm{g} / \mathrm{m}^{3}$, with averages of $83.3 \mu \mathrm{g} / \mathrm{m}^{3}$ in summer and $127.7 \mu \mathrm{g} / \mathrm{m}^{3}$ in winter. The average OC and EC concentrations in $\mathrm{PM}_{2.5}$ in winter were 1.3-2.3 times higher than those in summer. In total, 114 organic compounds were quantified and grouped into 12 classes. The dominant compounds in summer were $n$-alkanoic acids, followed by dicarboxylic acids and sugars. In contrast, sugars were the most abundant components in winter, followed by PAHs, $n$-alkanes, and $n$-alkanoic acids.

Seven sources were identified by the CMB model with organic tracers: wood/straw burning, coal burning, gasoline/diesel vehicle exhaust, cooking, and vegetative detritus, accounting for $64 . \pm 15 \%$ of the total ambient OC. Among the explained ambient OC, biomass burning was the dominant source in winter and Chinese cooking was the largest in summer. The contributions of biomass burning were $26 \%$ in winter and $11 \%$ in summer. Those of cooking were 17 $25 \%$ and that of coal burning was up to $17 \%$ in winter, but this dropped to $2 \%$ in summer. The contribution of vehicle exhaust was 13-20\%. Although CMB can not deal with secondary organic aerosol, the residual OC that could not be explained by the above sources may imply the upper limit of the contributions of secondary organic aerosols. In this paper, residual OC accounted for $44 \%$ and $22 \%$ of total ambient OC in summer and winter, respectively.

Acknowledgements. This work was supported by the Beijing Council of Science and Technology project (HB200504-6, HB200504-2). The Authors thank the discussion with Mei Zheng from Georgia Institute of Technology.

Edited by: U. Baltensperger

\section{References}

Beijing Municipal Bureau of Statistics and Beijing General Team of Investigation under the NBS (National Bureau of Statistics): Beijing Statistical Yearbook, China Statistics Press, 2006.

Cao, G., Zhang, X., Wang, D., and Zheng, F.: Inventory of emissions of pollutants from open burning crop residue, J. AgroEnviron. Sci., 24, 800-804, 2005.

Cao, G., Zhang, X., Wang, Y., and Zheng, F.: Estimating the pollutants discharged from crop residues burning in open field in China, Chinese Sci. Bull., 52, 1826-1831, 2007.

Cass, G. R.: Organic molecular tracers for particulate air pollution sources, Trends Anal. Chem., 17, 356-366, 1998. 
Chen, Y., Sheng, G., Bi, X., Feng, Y., Mai, B., and Fu, J.: Emission factors for carbonaceous particles and polycyclic aromatic hydrocarbons from residential coal combustion in China, Environ. Sci. Technol., 39, 1861-1867, 2005.

China Energy Yearbook Editorial Committee: China Energy Yearbook, Science Press, 2005/2006.

Feng, J., Chan, C. K., Fang, M., Hu, M., He, L., and Tang, X.: Impact of meteorology and energy structure on solvent extractable organic compounds of $\mathrm{PM}_{2.5}$ in Beijing, China, Chemosphere, 61, 623-632, 2005.

Fraser, M. P., Yue, Z. W., and Buzcu, B.: Source apportionment of fine particulate matter in Houston, TX, using organic molecular markers, Atmos. Environ., 37, 2117-2123, 2003.

Gao, X., Ma, W., Ma, C., Zhang, F., and Wang, Y.: Analysis on the current status of utilization of crop straw in China, J. Huazhong Agric. Univ., 21, 242-247, 2002.

He, L., Hu, M., Huang, X., Yu, B., Zhang, Y., and Liu, D.: Measurement of emissions of fine particulate organic matter from Chinese cooking, Atmos. Environ., 38, 6557-6564, 2004.

He, L., Hu, M., Huang, X., Zhang, Y., and Tang, X.: Seasonal pollution characteristics of organic compounds in atmospheric fine particles in Beijing, Sci. Total Environ., 359, 167-176, 2006.

Hildemann, L. M., Markowski, G. R., and Cass, G. R.: Chemical composition of emissions from urban sources of fine organic aerosol, Environ. Sci. Technol., 25, 744-759, 1991.

$\mathrm{Hu}, \mathrm{B} ., \mathrm{Zu}, \mathrm{H}$. and Qing, W.: A detailed list for exhaust in development models of automobile technology in China, J. WUT, Inform. Manage. Eng., 24, 99-102, 2002.

Huang, X., He, L., Hu, M., and Zhang, Y.: Annual variation of particulate organic compounds in $\mathrm{PM}_{2.5}$ in the urban atmosphere of Beijing, Atmos. Environ., 40, 2449-2458, 2006.

Lin, P.: Seasonal and diurnal variations of organic and elemental carbon in $\mathrm{PM}_{2.5}$ in Beijing and estimation of secondary organic carbon, Beijing, Peking University, China, Masters thesis, 2007.

NIOSH: NIOSH Manual of Analytical Methods; National Institute of Occupational Safety and Health: Cincinnati, OH, USA, 1996.

Oros, D. R. and Simoneit, B. R. T.: Identification and emission rates of molecular tracers in coal smoke particulate matter, Fuel, 79, 515-536, 2000.

Pope, C. A. and Dockery, D. W.: Health effects of fine particulate air pollution: lines that connect, Air Waste Manage. Assoc., 56, 709-742, 2006.

Ravindra, K. R., Sokhi, R., and Van Grieken, R.: Atmospheric polycyclic aromatic hydrocarbons: Source attribution, emission factors and regulation, Atmos. Environ., 42, 2895-2921, 2008.

Rogge, W. F., Hildemann, L. M., Mazurek, M. A., Cass, G. R., and Simoneit, B. R. T.: Sources of fine organic aerosol. 1. Charbroilers and meat cooking operations, Environ. Sci. Technol., 25, 1112-1125, 1991.

Rogge, W. F., Hildemann, L. M., Mazurek, M. A., Cass, G. R., and Simoneit, B. R. T.: Sources of fine organic aerosol. 2. Noncatalyst and catalyst-equipped automobiles and heavy-duty diesel trucks, Environ. Sci. Technol., 27, 636-651, 1993a.

Rogge, W. F., Hildemann, L. M., Mazurek, M. A., Cass, G. R., and Simoneit, B. R. T.: Sources of fine organic aerosol. 4. Particulate abrasion products from leaf surfaces of urban plants, Environ. Sci. Technol., 27, 2700-2711, 1993b.

Schauer, J. J.: Source contributions to atmospheric organic compound concentrations: emissions measurements and model pre- dictions, California Institute of Technology, Pasadena, CA, USA, Ph.D. dissertation, 1998.

Schauer, J. J. and Cass, G. R.: Source apportionment of winter gasphase and particle-phase air pollutants using organic compounds as tracers, Environ. Sci. Technol., 34, 1821-1832, 2000.

Schauer, J. J., Rogge, W. F., Hildemann, L. M., Mazurek, M. A., Cass, G. R., and Simoneit, B. R. T.: Source apportionment of airborne particulate matter using organic compounds as tracers, Atmos. Environ., 30, 3837-3855, 1996.

Schauer, J. J., Kleeman, M. J., Cass, G. R., and Simoneit, B. R T.: Measurement of emissions from air pollution sources. 2. C1 through C-30 organic compounds from medium duty diesel trucks, Environ. Sci. Technol., 33, 1578-1587, 1999a.

Schauer, J. J., Kleeman, M. J., Cass, G. R., and Simoneit, B. R T.: Measurement of emissions from air pollution sources. 1. C-1 through C-29 organic compounds from meat charbroiling, Environ. Sci. Technol., 33, 1566-1577, 1999b.

Schauer, J. J., Kleeman, M. J., Cass, G. R., and Simoneit, B. R. T.: Measurement of emissions from air pollution sources. 3. C1-C-29 organic compounds from fireplace combustion of wood, Environ. Sci. Technol., 35, 1716-1728, 2001.

Schauer, J. J., Kleeman, M. J., Cass, G. R., and Simoneit, B. R. T.: Measurement of emissions from air pollution sources. 5. $\mathrm{C}_{1}-$ $\mathrm{C}_{32}$ organic compounds from gasoline-powered motor vehicles, Environ. Sci. Technol., 36, 1169-1180, 2002.

Schnelle-Kreis, J., Sklorz, M., Orasche, J., Stolzel, M., Peters, A., and Zimmermann, R.: Semi volatile organic compounds in ambient $\mathrm{PM}_{2.5}$. Seasonal trends and daily resolved source contributions, Environ. Sci. Technol., 41, 3821-3828, 2007.

Simoneit, B. R. T.: Characterization of organic constituents in aerosols in relation to their origin and transport: a review, Int J. Environ. Anal. Chem., 23, 207-237, 1986.

Simoneit, B. R. T.: Biomass burning-a review of organic tracers for smoke from incomplete combustion, Appl. Geochem., 17, 129-162, 2002.

Simoneit, B. R. T. and Elias, V. O.: Organic tracers from biomass burning in atmospheric particulate matter over the ocean, Mar Chem., 69, 301-312, 2000.

Simoneit, B. R. T. and Elias, V. O.: Detecting organic tracers from biomass burning in the atmosphere, Mar. Pollut. Bull., 42, 805$810,2001$.

Song, X. and Xie, S.: Development of vehicular emission inventory in China, Environ. Sci. 27, 1041-1045, 2006.

Song, Y., Tang, X., Fang, C., Zhang, Y., Hu, M., Zeng, L., Li, C., Mao, J., and Michael, B.: Relationship between the visibility degradation and particle pollution in Beijing, Acta Sci. Circum. 23, 468-471, 2003.

Song, Y., Zhang, Y., Xie, S., Zeng, L., Zheng, M., Salmon, L. G., Shao, M., and Slanina, S.: Source apportionment of $\mathrm{PM}_{2.5}$ in Beijing by positive matrix factorization, Atmos. Environ., 40, 1526-1537, 2006

Song, Y., Tang, X., Xie, S., Zhang, Y., Wei, Y., Zhang, M., Zeng, L., and Lu, S.: Source apportionment of $\mathrm{PM}_{2.5}$ in Beijing in 2004, J. Haz. Mater., 146, 124-130, 2007.

Sun, Y., Zhuang, G., Zhang, W., Wang, Y., and Zhuang, Y.: Characteristics and sources of lead pollution after phasing out leaded gasoline in Beijing, Atmos. Environ., 40, 2973-2985, 2006.

Wang, J., Xie, Z., Zhang, Y., Shao, M., Zeng, L., Cheng, C., Xu, Z., Zhao, X., and Meng, Y.: The research on the mass concentration 
characteristics of fine particles in Beijing, Acta Meteorol. Sin., 62, 104-111, 2004.

Wang, Q., Shao, M., Liu, Y., William, K., Paul, G., Li, X., Liu, Y., and Lu, S.: Impact of biomass burning on urban air quality estimated by organic tracers: Guangzhou and Beijing as cases, Atmos. Environ., 41, 8380-8390, 2007.

Wang, X. and Feng, Z.: Biofuel use and its environmental problems in rural areas of China, J. Nanjing Agric. Univ., 27, 108-110, 2004.

Yang, F., He, K., Ye, B., Chen, X., Cha, L., Cadle, S. H., Chan, T., and Mulawa, P. A.: One-year record of organic and elemental carbon in fine particles in downtown Beijing and Shanghai, Atmos. Chem. Phys., 5, 1449-1457, 2005, http://www.atmos-chem-phys.net/5/1449/2005/.

Yu, S., Lin, X., and Xu, X.: Temporal and spatial characteristics of air pollution in Beijing, J. Appl. Meteorol. Sci., 13, 92-99, 2002.

Zhang, Y.: Study on speciation of particulate organic matter from combustion sources, Beijing, China, Peking University, Ph.D. dissertation, 2006.

Zhang, Y., Shao, M., Zhang, Y., Zeng, L., He, L., Zhu, B., Wei, Y., and Zhu, X.: Source profiles of particulate organic matters emitted from cereal straw burnings, J. Environ. Sci., 19, 167$175,2007$.
Zhang, Y., Schauer, J. J., Zhang, Y., Zeng, L., Wei, Y., Liu, Y., and Shao, M.: Characteristics of particulate carbon emissions from real-world Chinese coal combustion, Environ. Sci. Technol., 42, 5068-5073, 2008.

Zhao, Y.: Study on speciation of particulate organic matter from combustion sources, Beijing, Peking University, Ph.D. dissertation, 2006.

Zhao, Y., Hu, M., Slanina, S., and Zhang, Y.: Chemical compositions of fine particulate organic matter emitted from Chinese cooking, Environ. Sci. Technol., 41, 99-105, 2007.

Zheng, M., Salmon, L. G., Schauer, J. J., Zeng, L., Kiang, C. S., Zhang, Y., and Cass, G. R.: Seasonal trends in $\mathrm{PM}_{2.5}$ source contributions in Beijing, China, Atmos. Environ., 39, 3967-3976, 2005.

Zhu, B., Zhu, X., Zhang, Y., Zeng, L., and Zhang, Y.: Emission factor of $\mathrm{PM}_{2.5}$ from crop straw burning, Res. Environ. Sci., 18, 29-33, 2005. 